\title{
Reflections on Post-graduate education in Social Work in Brazil through the staff profile
}

\author{
Maria Lúcia Teixeira Garcia \\ Federal University of Espírito Santo (UFES)
}

\author{
Vera Maria Ribeiro Nogueira \\ Catholic University of Pelotas (UCPel)
}

\section{Reflections on Post-graduate education in Social Work in Brazil through the staff profile}

Abstract: This article addresses issues related to the staff of Post-Graduate programs in Social Work in Brazil. Initially, it traces a retrospective of Post-Graduate education in the country and describes the structure of Social Work in three moments: the initial period, through the 1970's and 1980's; the period of expansion, between 1990 and 2005; and the current period, between 2006 and 2016. It points out the impasses experienced by the first programs in relation to the lack of Doctors. Next, it presents the current profile of the professors who are part of Social Work programs. Data were obtained from CAPES, Geocapes and program reports, and analyzed through descriptive statistical analysis and content analysis. In conclusion, it evidences a growing tendency towards qualification and a marked expansion of the number of teaching staff after the year 2000. The growth of doctoral courses is noteworthy, however, the relation between teaching staff and students did not change significantly in percentage terms.

Keywords: Social Work.Higher Education.Post-Graduate Programs. Staff Profile. 


\section{Introduction}

This article addresses issues related to the Staff of post-graduate programs in Social Work in Brazil, highlighting the profile of professors linked to these programs. As professors of post-graduate programs, we wondered: How did the first programs relate to the structure of their Staff? Who are the professors today? What changes have occured in the staff profile, bearing in mind the demand for interdisciplinarity in this subject area? These issues are important, considering the characteristics of the subject area in the Coordination for the Improvement of Higher Education Personnel (CAPES): there are now 32 post-graduate programs linked to Social Work, 23 in Social Work, and 9 in Social Policy or Public Policies (we have excluded two programs from the Home Economics area that belong to area 32 - Social Work). To this end, we carried out an analysis from a historical perspective, considering three moments in time: the initial period of the creation of the first programs in the area, through the 1970's and 1980's; the period of expansion, between 1990 and 2005; and the current period, between 2006 and 2016. This division takes into account the data available on Brazilian post-graduate education in general and Social Work in particular. We conducted documentary research in the CAPES collection on post-graduate programs in Social Work ${ }^{1}$, in addition to data available in the GeoCapes ${ }^{2}$ system and the evaluation reports of the post-graduate programs available on the CAPES website.

The documents were read and organized in tables, containing data on: Staff (number, education, HEI, gender, degree area) and the main challenges posed to the area in terms of staff composition (qualification, numbers and the percentage relation between students and professors). For the data analysis, we used descriptive statistical analysis and content analysis.

In the process of human resources qualification at post-graduate level, a qualified staff is required to deliver the proposed course and to guarantee the achievement of its objectives. After forty-four years, since the creation of the first post-graduate program in the area of Social Work, it is time to reflect on the subjects that have been assuring the consolidation of the subject as an area of knowledge. It should be noted that the topic of Post-Graduate Education in Social Work has already been studied by other authors (CARVALHO, SILVA, 2005; SILVA, CARVALHO, 2007, GUERRA, 2011). However, none of these studies has explored the focus proposed for this study.

\section{Graduate education in Brazil and the first steps of the Social Work subject area}

The first steps of post-graduate education in Brazil were taken at the beginning of the 1930's, in the proposal set out in the Statute of Brazilian Universities, in which Francisco Campos (Minister of Education and Health of the Getúlio Vargas government) advocated the introduction of post-graduate education inspired by European post-graduate programs (SANTOS, 2003). The arrival of foreign professors and the adoption of a model based on a tutorial system is registered- a professor and his/her disciples, who would be the future staff of universities ${ }^{3}$.

In terms of the first post-graduate programs in Brazil, the Free School of Sociology and Politics (ELSP) and the University of São Paulo (USP), from the 1940s, were pioneers. After these, there were the initiatives of the Aeronautics Institute of Technology (ITA) and the Agronomy Schools, in the early 1960s (CÓRDOVA; GUSSO; LUNA, 1986). However, post-graduate education in its institutionalized form emerged in the country only in the early 1960s, not as a spontaneous result of the growth of scientific publications or of the qualification of scientists, but of a deliberate state policy. The aim was to modernize the university through the implementation of post-graduate programs (DURHAM, 1986). In Brazil, through the 1960's and 1970's, the expansion of postgraduate education was partially spontaneous. With the military governments measures to expand the system were established, based on an organizational structure similar to that of the North American model, (SANTOS; AZEVEDO, 2009).

Between 1965 and 1968, under the military governments of Castello Branco and Costa e Silva, we highlight Opinion No. 977 CES/CFE, dated December 3, 1965, known as the Newton Sucupira Opinion, and the University Reform Law of 1968. In both documents, education is correlated to economic development and they are linked to the projects of the military governments, which planned a model of higher education, of university and, consequently, of post-graduate education, to meet this goal. The 1968 Reform modernized a significant portion of federal universities, abolishing the lifelong university chairs, introducing the departmental structure, institutionalizing the academic career, and creating legislation that coupled professor appointment and progression to academic degrees. In order to meet this requirement, a national post-graduate education policy was created, which was then expressed in the national post-graduate education plans (MARTINS, 2009). The University Reform Law created departments with rotating management, the credit system, the qualifying entrance exam, 
"vestibular" (which was formerly eliminatory), short duration courses, the basic cycle, full-time employment and exclusive contractual dedication. Strengthening the link between education and research, the reform placed value on academic degrees and scientific publications, making way for a greater professionalization of the staff and for post-graduate education in the country.

If the university reform of 1968 opened up the conditions for the emergence of a private education, which reproduced what Florestan called the old Brazilian standard of higher education - institutions organized from isolated establishments, focused on the transmission of professionalizing knowledge, distanced from research activity - it contributed little to a critical qualification (FERNANDES, 1975; MARTINS, 2009). The demand for vacancies at federal universities failed to pressure the federal government to expand the public system, which opened a market niche for the expansion of private education, mainly in the suburbs of metropolises and medium-sized cities in the more developed States (SOARES, 2002) . $^{4}$

It was, therefore, in the context of the Military Dictatorship, that post-graduate education experienced movement towards structuring, standardization and institutionalization, as well as expansion of the promotion, expansion and adoption of evaluation systems, whose guidelines and basis remains today.

The years 1960-1970 were a period of creation of programs of different subject areas, fulfilling the political demands and the interests of expansion of post-graduate education to meet the demands of the country at the time of developmentalism. For example, of the 48 knowledge areas existing in 2016 at CAPES, 28 had their oldest programs created between 1960 and 1969, and 18 between 1970 and 1974. The latter includes: Geography, Social Work, Architecture, Arts, Applied Social Sciences I, Law, Nursing, Education, Pharmacy, Philosophy, History, Medicine I, Medicine II, Medicine III, Veterinary Medicine, Nutrition, Urban Planning and Public Health.

The CAPES Post-Graduate Evaluation System was implemented during the military dictatorship under General Ernesto Geisel, a period marked by an increase in external indebtedness, worsening of the annual inflation rate (from $20 \%$ to $40 \%$ ), hyperinflation, increasing unemployment and insecurity of formal employment. It was also a period of expansion of the post-graduate education system, with annual rates of growth in the number of Master's and Doctoral programs of the order of 100\% (GUIMARÃES; CARUSO, 1996).

This growth is recorded in documents for this subject area, that justify the importance of the implementation of the Master's degree. In the accreditation process of the PUCSP Master's program ${ }^{5}$, the area Coordination registered this increase in the 1964/1977 period, the increase in enrollment for the entrance examination was explosive, reaching an increase of 956\%, according to a document from the Institute for Applied Economic Research (IPEA). It had become an imperative, therefore, to adequately prepare professors to improve of the quality of university education.

Between 1974 and 1979 the transfer of the headquarters of CAPES to Brasília took place, with the decentralization of the responsibility for selecting, monitoring, paying and evaluating the performance of scholarship holders at the universities. The establishment of a new scheme for the supervision and classification of post-graduate courses also took place, which was initially performed by advisory

After forty-four years, since the creation of the first postgraduate program in the area of Social Work, it is time to reflect on the subjects that have been assuring the consolidation of the subject as an area of knowledge. committees. Initially with one representative per area, though this number was later increased, the committees became the basis of a new decision-making process, compiling the definitions of institutional quotas of scholarships allocated to each course, the selection of scholarship holders to go abroad and the establishment of guidelines and priorities for sectorial actions (CAPES, 1994). Throughout the 1970s, about 800 new Master's and Doctoral courses ${ }^{6}$ were created (DURHAM; GUSSO, 1991). In this decade the country was experiencing its last growth spurt based on the so called nationaldevelopmental model (GUIMAR ÂES, 2002).

In the expansion of the programs, two growth processes can be identified. The first between the 1960's and 1990's ${ }^{7}$ and a second since the year 2000, with strong distinctions between the two moments in regard of the issue of gender and related to the locus of the degree. The study shows that in Brazil 14,173 Doctors graduated abroad between 1970 and 2014. Of this total, 8,357, or 59\%, were men and 5,786, or 41\%, were women. The proportion of graduations abroad has fallen sharply, of the research Doctors registered in the directory of groups of the National Council for Scientific and Technological Development (CNPq), who graduated until 1985, about 40\% had graduated abroad (VELLOSO, 2004). 
Until 2011, men were more absent from Brazil to obtain their degree. In 1970, only 12 women had graduated abroad while 29 men had done the same. From 2012, this picture changes, and women Doctors outnumber men. In 2014, 464 women took their Doctorate abroad, men with the same degree numbered 291.

The tendency for growth in post-graduate education remained until the 1990s, at which point the system registerer an accelerated growth. However, this post-graduate education expansion, in population terms, was still modest ( $0.1 \%$ of the population had a Doctoral degree and $0.3 \%$ had a Master's degree) (IBGE, 2012). This growth formed part of an action present in the National Postgraduate Plans (PNPG). In the I PNPG (1975-1979), there is the recognition that the expansion should become the object of state planning, seeing postgraduate education as a sub-system of the university system and this, in turn, of the educational system (BRASIL, 1979). In the IV PNPG, the post-graduate education expansion notes the growth of the subject area and the existing regional imbalance (CAPES, 2004).

Specifically regarding the post-graduate program in Social Work, the scenario indicates that there was a concern with the instructions of the IV PNPG, observing a growth of the subject area and a small reduction in regional imbalances, as it is noted next, in $2016^{8}$. Today there are 34 programs linked to area 32 (Social Work) in CAPES, which are distributed spatially: 12 in the Southeast region (36.4\%), 11 in the Northeast region (33.3\%), 5 in the South region (15, 2\%), 3 in the Midwest region (9\%) and 2 in the North region (6\%). Of the programs, $69.7 \%$ are concentrated in the Southeast and Northeast regions.

When comparing the data of the subject area with the general data of the National Graduate System, we observed that it has, in percentage, its highest number of Programs in the Northeast region (SNPG - 19.8\% and area $32-32.5 \%)$.

In post-graduate qualifications in Social Work, the public universities lead (78.8\%), followed by community universities (15.2\%), with private institutions showing very little (6\%), demonstrating an inverse tendency to the one observed in undergraduate education. Of the public universities, 18 are Federal and 8 are State (24.2\%). The expansion of State universities (from 3 in 2010 to 8 in 2015 - a $266 \%$ growth) and the reduction of programs in private universities are highlighted (the change in the Social Policy Program subject area of UCSAL is also recorded). Of the 6 institutions, 5 are community institutions (4 PUCs and 1 Catholic University (UCPEL)) and one is non-profit (EMESCAM).

In 2016, 18 Doctoral courses (PUCRS, PUC-SP, PUC-Rio, UFMA, UFRJ, UFPE, UnB, UNESP, UERJ, UFPE, UFF, FUFPI, UFES, UFV, UEL, UFSC, UCPel, UFRN and UFPA) and 34 Master's courses ${ }^{9}$ were operative. The situation of post-graduate programs in relation to the subject area is as follows: 23 in Social Work (67.6\%); 6 in Social Policy (17.6\%); 3 in Public Policies (8.8\%), and 2 in Home Economics (5.9\%). It is in this context that Brazilian Social Work is configured and expands as an area of knowledge. Furthermore, professors are also subjects of this process.

\subsection{The implementation of graduate programs in Social Work and the configuration of their staff}

In the area of post-graduate qualifications, the area of Social Work integrated, at the time of its creation, the Great Area of Social Professions. In the 1970s, the first programs were created, the first being in 1971 at the Pontifical Catholic University of São Paulo (PUC-SP), followed by the Pontifical Catholic University of Rio de Janeiro (PUC-Rio) and, in 1976, the Graduate Program of the Federal University of Rio de Janeiro (UFRJ) and the Pontifical Catholic University of Rio Grande do Sul (PUCRS) in 1977. The first reference to a Social Work consultant in appears in 1976, the representative being Professor Margaret Jenks - professor of PUCRio in the late 1970s, who was designated through Resolution n. 10/1976, of the CAPES Technical-Administrative Council. One aspect to be highlighted in relation to the expansion of post-graduate programs in the area was the lack of qualified staff members under the terms demanded by CAPES at the time. This situation is expressed in Opinion No. 2,135/1978, of the Higher Education Chamber (CESU), which refers to the staff within the PUC-SP proposal:

The Federal Council of Education, meeting in full session [...] unanimously decided to issue the process in diligence, in order that the university is given a new opportunity to provide the reinforcement of staff qualified in the specific area of the course, along with the extension of the current professors' working hours and/or the hiring of new professors, also with sufficient dedicated contact hours, so that the resulting group may attend to the teaching and advising of the Master's students [since at first analysis only 3 professors would be able to advise], in adequate proportion to the number of offered vacancies[...] Of these professors, one, without a formal graduate degree, overcomes it, however, by excellent qualifications in the professional field and in scientific publication, in specialized books and periodicals, national and foreign. 
Five are holders of Doctoral degrees (PUC-SP) to which two add recordable scientific publication. The seventh one has only a Master's degrees (Administration in Public Health and Social Work), however, 6 published studies (BRASIL, 1978, our italics).

Subsequently, the importance of the staff qualifications appears as a justification for the creation of postgraduate programs in Social Work, as shown in Opinion n. 1,538, dated November 8, 197910: 50 Social Work Schools in Brazil, and only 3 Master's Courses in operation: 1 in PUC in São Paulo, 1 in PUC in Rio and 1 in PUC in Rio Grande do Sul, insufficient to meet the need for qualified staff at this level. This lack prompted the urgency of the expansion of Masters and Doctorates in Social Work. This expansion implied a period of transition that included a staff of Masters and Doctors. The configuration of the staff was, therefore, a relevant question that was presented at the opening of the first Master's courses in the subject area. The area did not have (as in other areas) a number of post-graduated Doctors to open their programs. The opening of the first programs was dependent on the degree, at the Doctorate level, of its professors. This aspect was repeated in the Opinion on the question of staff presented in the proposal for renewal of the accreditation of UFRJ Master's program $^{11}$, i.e. the staff (at UFRJ) is of recognized competence and experience in the area. Its qualifications, from the formal point of view, are considered adequate and with a likelihood of improving in the short term, due to the upcoming qualification of 9 professors who are defending their Doctoral thesis.

The qualification of professors for the subject area was a challenge to be overcome, not just in Brazil, but in other Latin American countries too. In the 1980s, when the proposal to open a Doctoral program at PUC-SP ${ }^{12}$ was presented, one of the justifications was the leadership position of Brazilian Social Work in the Latin American context. The Doctoral program in Social Work of PUC-SP was the only one in Brazil and in Latin America and one of the rare ones at an international level ${ }^{13}$. In this sense, it is important that this initiative has the participation and cooperation of the set of post-graduate programs in Social Work in the country, in order to provide a body of scientific publications that reveals and explains the specific problems of Social Work at a national level and to respond to its main theoretical-methodological concerns. This situation of the post-graduate courses in the subject area, relying on few Doctorate professors in Social Work, in the 1980's, was thus described:

Currently, the six Master's courses in Social Work that exist in the country (with the exception of the one of PUC-SP) do not have among their staff any Doctors in Social Work, although some have a Bachelors in Social Work with a Doctoral degree in another area. The existence of few courses in this area and at a world level, as well as the fact that the existing ones (mainly in North America) maintain programs that are remote from the Brazilian and Latin American problems, do not attract our professionals. ${ }^{14}$

This deficit in the staff qualifications is recurrent, as stated in the document of PUC-SP: "In 1982, the Master's courses in Social Work in Brazil had 27 Masters in their permanent staff who constitute the potential and target clientele of the present project"15 (New Course Proposal Evaluation of PUC-SP, 1980, our quotes). That is, it was necessary to qualify the staff of the six post-graduate programs in the area in that period.

The faculty of PUC-SP, in the early 1980s, was composed of seven Doctors, five of them from the Social Work area, with degrees obtained outside the country. This small number of professors is reiterated once again in CAPES's view: "the dimension of this is quite insufficient considering the number of students, the two strict sense post-graduate levels that it maintains, and the working hours of these professors" 16 .

In the response to the CAPES's opinion, PUC-SP argues that its staff consisted of 6 Doctors in Social Work, 2 in Political Science, 1 in Philosophy and 2 Masters enrolled on a Doctoral program.

Professors' qualifications were also criticized by CAPES, at the time of the submission of the Doctoral project by $\mathrm{PUC}-\mathrm{SP}^{17}$. In its appeal to the opinion, PUC-SP questions the received criticism regarding the excessive endogeny and lack of critical mass of its staff.

The College of Social Work of PUC-SP is the oldest one in Brazil. It was also the first one to implement a Postgraduate course. Through the Special Doctoral Program of PUC-SP -it qualified the first Doctors in Social Work in the country. For this reason, any Social Work professor with a degree that was hired, outside PUCSP, would have had relations with PUC or would even have taken courses at PUC-SP. It would be appropriate for CAPES to survey the Master's and Doctoral Programs in Social Work with their implementation date, etc.

On a visit to the same program in March 1982, the reporter indicated that the course had "a faculty of 11 permanent professors, of whom 7 are Doctors, 2 Masters and 2 with specializations, which qualifies it as a more widely qualified staff among the Post-graduate Programs of Social Work"18 (our quotes). In 1984, in a 
new visit report, the faculty consisted of 14 Doctors, 1 full professor, 7 Masters (of which 4 were Doctoral students in PUC-SP) and 3 with a Bachelor's degree ${ }^{19}$.

In 1990 the evaluation report records that in the biennium, there was an expansion of the faculty from 13 permanent professors in 1989, to 15 in 1990 and 16 in 1991. The number of professors had also increased.

In addition, the Course maintained, during the period, professors attending the Doctoral program: professors who maintained advising activities (with one exception) and one who continued teaching in 1991, 4 professors maintained their advising activities, of which, one also continued teaching. ${ }^{20}$

The composition of the staff of UFPB, the first program of the Northeast region in 1978, followed the same tendency:

[...] of the twelve (12) permanent professors, nine (9) are social workers, eight (8) of whom are Masters and one is a Doctor in Social Work. The other three (3) professors are Doctors, respectively in the areas of Methodology of Education, Social Sciences and Philosophy. Of the eight (8) social work professors, four (4) carry out teaching activities and only one advises theses and conducts research. ${ }^{21}$

This composition of professors without a Doctoral degree appears in 1999, in the UERJ report, which included $90 \%$ of Doctors, $40 \%$ with qualification or degree in the basic area. In its proposal to create the Master's degree, UFSC described its faculty as follows:

[...] for the initial stage of implementation of the Master's Program in Social Work, the permanent faculty (3 full time Doctors from the Department of Social Work, qualification of 2 more Doctors, respectively in 1998 and 1999, as well as a possible transfer of a Doctor of Social Work from the Department of Social Work of UFSC) meets the basic requirements of teaching, research and advice..$^{22}$

With regard to the project to create the UFSC Master's degree course, the evaluators of the area justified their opinion in the light of it being the first course in a public HEI in the South. Their opinion also highlighted that this proposal for a Master's degree was the first one to make the interdisciplinary approach explicit.

As in previous cases, the size of the faculty will be questioned in opinions issued during the CAPES assessment by the Technical Advisory Group ${ }^{23}$, 'the size of the faculty is insufficient to meet teaching and advising activities required by a post-graduate program' (Opinion of the CAPES Area Committee to the New Course Proposal Evaluation of UFSC, Oct. 1996).

One of the alternatives found by some programs to overcome the impasses due to staff qualification at the Doctoral level was the initial inclusion of the participation of external members. At the time, these proposals were also criticized in the opinion issued by CAPES consultants:

The size of the faculty is adequate, however, it still depends heavily on external professors. There is no exclusive responsibility of the permanent professors in relation to the courses taught, all of them have the participation of external professors. [...] The proportion of Doctors is low (less than 50\% of the faculty) (Opinion of the CAPES Area Committee to the New Course Proposal Evaluation of UFMA, 1993) ${ }^{24}$.

Only from the 2000's, with the progressive expansion of post-graduate programs in the area, was the staff composed solely of Doctors. This expansion also made the post-graduate programs in Social Work possible, a staff constituted with $60 \%$ of its members holding a bachelor's degree or a post-graduate degree in Social Work. The growth of post-graduate programs in the area of Social Work between 1996 and 2014 was 233.33\% for Master's courses and 700\% for Doctoral courses (CENTRO DE GESTÃO E ESTUDOS ESTRATÉGICOS, 2016). Furthermore, in 2014, $76.1 \%$ of the Doctors qualified in the area were employed.

\section{The profile of professors of post-graduate education in Social Work in Brazil (2000-2015)}

The number of professors linked to post-graduate programs in Social Work between 2000 and 2015 rose from 107 to 418 professors. This growth is significant if we consider that between 1998 and 2000, the average was 8 professors per program and in 2015 this ratio changed positively to 12 professors per program. Regarding gender, the 
ratio of female to male is 3.3:1. Despite the predominance of women, the ratio is different from the one recorded in the profile of Brazilian social workers (slightly more than 90\%). This difference is due to the number of professors of related areas of knowledge that integrate the programs of the Social Work area. Regarding qualifications, the data indicate that $49.4 \%$ of the professors have a Doctoral degree in Social Work, followed by degrees in all major areas of knowledge, this highlights the large subjects areas of Applied Social Science and Human Science (such as Sociology, Education, Anthropology, Economics, Political Science, Psychology, History and Philosophy). As for the professors' age, most were born in the 1960s (43.3\%), followed by the $1950 \mathrm{~s}(25.3 \%)$ and $1970(16.6 \%)$. There is also the entrance of younger Doctors (1.8\% were born in the 1980s) and the presence of very experienced Doctors (born between the 1930 s and 1940 s $-13.4 \%$ ). A process of gradual renewal of the staff that composes the post-graduate program is underway. The highest number of qualifications of these professors occurred between 2000 and 2009 (65\%), accompanying the period of expansion of the National Post-graduate System.

The growth of PPGs (Post-graduate Programs) in the area of Social Work was incorporating the new post-graduates. By 2014, the 31 programs had 406 professors (13 professors per program). This growth is significant when we consider that, between 1998 and 2000, there were, on average, 8 professors per program. Among the categories of professors, $78.5 \%$ of the total in 2015 were permanent (CAPES, 2016 , p. 14). This percentage shows that the number of collaborating professors had grown. In 2004, permanent professors accounted for $94 \%$. This variation follows the changes in the staff, following the guidelines established by CAPES, over the last 10 years (the last two ordinances were no. 174 of 2014 and no. 81 of 2016) (CAPES, 2014, 2016).

The growth of programs and staff has contributed to a reduction in the proportion of students per professor. In the triennial 1998-2000, the ratio was 5.7:1. By 2015, this ratio is 4:1. Professors are, for the most part, public servants $(76 \%)$. It is recorded that in $20151 \%$ of permanent professors are retired professors and $23 \%$ are professors employed under the terms of "Consolidation of Labor Laws" (CLT). The process of Professor's retirement, due both to age and the fear of changes in Social Insurance, have a significant impact on the permanent staff of the programs, especially in public institutions. The renewal process is ongoing. Furthermore, the percentage of retirement aged professors still working also indicates their importance in the dynamics of the programs (which keep them in permanent jobs), but it also expresses the insecurity that this entails: the taking-on of teaching, research and advising activities by retired professors through voluntary work contracts.

\section{Final considerations}

This article addressed faculty staff as one of the aspects of the post-graduate qualification process, evidenced its relevance in the process of consolidating PPGs in the subject area and highlights the impasses related to the qualifications in these subjects at the beginning of the institutionalization of staff and how they were overcome as a result of the collective effort of the programs in the qualification of Doctors to meet the existing demand. We sought to understand our object by situating it in the historical perspective of the expansion of Post-graduate Education and in the configuration of higher education policy that prioritized the expansion of this level of qualification. This expansion was not accompanied by actions that ensured the qualification of professors, i.e. the growth of scholarship quotas did not proportionally accompany the growth of vacancies.

The synchronocity between the implementation of the first Social Work programs and the beginning of post-graduate education consolidation between 1960 and 1990, i.e. in the first moment of this process, contradicts some who say that this is still a recent subject area on the post-graduate education scene in Brazil. In addition to this first move towards institutionalization and bearing in mind the difficulties with professor qualifications and the successful strategies of programs in this area, the rapid development of the programs of the area favored the placement of the new Doctors and the carrying out of post-doctoral studies. This has formed, today, a staff with the required competences, compatible with the demands of Brazilian society. The data presented here, in relation to the staff profile, shows the changes in age, with a growth of the number of Doctors aged around 50. This profile points to a process of expansion and renewal.

The growing importance of interdisciplinarity, the specifics of Brazilian society in relation to the expression of social issues and the demands to confront them, have been answered by these programs. They have retained, within their staff, professionals with diverse qualifications, favoring the qualification of researchers and professors within a overall vision and competent to face the current serious challenges, both internal to universities and external that fall on Brazilian society. This confrontation, within the scope of post-graduate qualifications, especially by the staff, has to maintain the rigor of the critical method and consolidate collective and democratic positions in academia. 


\section{References}

BELTRÃO, K. I.; TEIXEIRA, M. P. O vermelho e o negro: raça e gênero na universidade brasileira: uma análise da seletividade das carreiras a partir dos censos demográficos de 1960 a 2000. Brasília (DF): IPEA, 2004. (Texto para Discussão, n. 1052). Disponível em: <http://repositorio.ipea.gov.br/bitstream/11058/1893/1/TD_1052.pdf >. Acesso em: 10 ago. 2016. BRASIL. Coordenação de Aperfeiçoamento de Pessoal de Nível Superior. IV Plano Nacional de Pós-Graduação. Brasília (DF), 2004. Disponível em: <http://www.capes.gov.br/images/stories/download/editais/PNPG_2005_2010.pdf>. Acesso em: 5 ago. 2016.

. Coordenação de Aperfeiçoamento de Pessoal de Nível Superior. O papel do CTC. InfoCapes, Brasília (DF), v. 2, n. 4, out./dez. 1994, p. 14-18. Disponível em: 〈https://www.capes.gov.br/images/stories/download/bolsas/Info4_94x1x.pdf >. Acesso em: 5 ago. 2016.

. Coordenação de Aperfeiçoamento de Pessoal de Nível Superior. Portaria n. 81, de 3 de junho de 2016. Define as categorias de docentes que compõem os Programas de Pós-Graduação (PPGs) Stricto Sensu. Diário Oficial [da] República Federativa do Brasil, Poder Executivo, Brasília (DF), 6 de junho de 2016. Seção 1, p. 14. Disponível em: <http://www.capes.gov.br/images/stories/download/ legislacao/06062016-PORTARIA-N-8-De-3-DE-JUNHO-DE-2016.pdf>. Acesso em: 10 ago. 2016.

. Coordenação de Aperfeiçoamento de Pessoal de Nível Superior. Portaria n. 174, de 30 de dezembro de 2014. Define, para efeitos de enquadramento nos programas e cursos de pós-graduação e das avaliações, as categorias de docentes dos programas desse nível de ensino. Diário Oficial [da] República Federativa do Brasil, Poder Executivo, Brasília (DF), 31 de dezembro de 2014. Seção 1, p. 86. Disponível em: <http://www.capes.gov.br/images/stories/download/legislacao/PORTARIA-N-174-DE-30-12-2014.pdf〉. Acesso em: 10 ago. 2016.

. Ministério da Educação. Câmara de Ensino Superior. Parecer n 2.135/1978. Brasília (DF), 1978.

Ministério da Educação e Cultura. Conselho Nacional de Pós-Graduação. Departamento de Documentação e Divulgação. I Plano Nacional de Pós-Graduação. Brasília (DF), 1979. Disponível em:

<http://www.capes.gov.br/images/stories/download/editais/I_PNPG.pdf>. Acesso em: 5 ago. 2016.

CARVALHO, D. B. B.; SILVA, M. O. S. (Orgs.). Serviço Social, Pós-Graduação e produção de conhecimento no Brasil. São Paulo: Cortez, 2005.

CENTRO DE GESTÃO E ESTUDOS ESTRATÉGICOS. Mestres e doutores 2015: estudos da demografia da base técnico-científica brasileira. Brasília (DF), 2016. Disponível em: 〈https://www.cgee.org.br/documents/10182/734063/Mestres_Doutores_2015_Vs3.pdf〉. Acesso em: 10 ago. 2016.

CÓRDOVA, R. A.; GUSSO, D. A.; LUNA, S. V. A pós-graduação na América Latina: o caso brasileiro. Brasília: UNESCO/MEC, 1986. CROW, R.T.; KINDELSPERGER, K. W. The PhD or the DSW? Journal of Education for Social Work, v. 11, n. 3, p. 38-43, mar. 1975. DURHAM, E. A política de pós-graduação e as Ciências Sociais. BIB, Rio de Janeiro, n. 21, p. 41-45, primeiro semestre 1986.

.; GUSSO, D. Pós-graduação no Brasil: problemas e perspectivas. Brasília (DF): CAPES, 1991. Mimeo.

FERNANDES, F. Universidade brasileira: reforma ou revolução? São Paulo: Alfa-Ômega, 1975.

GUERRA, Y. D. A Pós-Graduação em Serviço Social no Brasil: um patrimônio a ser preservado. Temporalis, Brasilia (DF), ano 11, n. 22, p.125-158, jul./dez. 2011.

GUIMARÃES, R. Pesquisa no Brasil: a reforma tardia. São Paulo Perspec., São Paulo, v. 16, n. 4, p. 41-47, out./dez. 2002. Disponível em: 〈http://www.scielo.br/scielo.php?script=sci_arttext\&pid=S0102-88392002000400008\&lng=en\&nrm=iso>. Acesso em: 3 ago. 2016.

.; CARUSO, N. Notas sobre o estado da arte e elementos para uma política. InfoCapes, Brasília (DF), v. 4, n. 3, jul./set. 1996, p.7-18. Disponível em: <http://www.capes.gov.br/images/stories/download/bolsas/Info3_96.pdf>. Acesso em: 05 ago. 2016.

IBGE. Censo demográfico 2010: Resultados do Universo do Censo Demográfico 2010. Rio de Janeiro, 2012. Disponível em: <ftp://ftp.ibge.gov.br/Censos/Censo_Demografico_2010/Resultados_do_Universo/tabelas_pdf/tab5.pdf>. Acesso em: 4 ago. 2016. JOSETTI, C. C.; ARAÚJO, R. V. C. Educação nas décadas de 1920 a 1950 no Brasil: alfabetização de adultos em questão. Revista Fórum Identidades, Aracajú, ano 6, v. 12, p. 183-192, jul./dez. 2012.

KOIKE, M. et al. Caracterização da área de Serviço Social (Comissão de Especialistas de Ensino em Serviço Social. SESu/MEC). Cadernos ABESS, São Paulo, v. 7, p. 77-92, 1997.

MARTINS, C. B. A Reforma universitária de 1968 e a abertura para o ensino superior privado no Brasil. Educação e Sociedade, Campinas, v. 30, n. 106, p. 15-35, jan./abr. 2009.

SANTOS, A. L. F.; AZEVEDO, J. M. L. A pós-graduação no Brasil, a pesquisa em educação e os estudos sobre a política educacional: os contornos da constituição de um campo acadêmico. Revista Brasileira de Educação, Rio de Janeiro, v. 14, n. 42, p. 534-550, set./dez. 2009.

SANTOS, C. M. Tradições e contradições da Pós-Graduação no Brasil. Edução e Sociedade, Campinas, v. 24, n. 83, p. 627-641, ago. 2003.

SAVIANI, D. O legado educacional do "Breve Século XIX” brasileiro. In: SAVIANI, Dermeval et al. O legado educacional do Século XIX. Campinas: Autores Associados, 2006.

SILVA, M. O. S.; CARVALHO, D. B. B. A pós-graduação e a produção de conhecimento no Serviço Social brasileiro. RBPG, Brasília (DF), v. 4, n. 8, p. 192-216, dez. 2007. 
SOARES, M. S. A. (Coord.). Educação superior no Brasil. Brasília (DF): MEC/CAPES; Caracas: Unesco/Iesalc; Porto Alegre: UFRS/ IFCH/GEU, 2002.

VELLOSO, J. Mestres e doutores no país: destinos profissionais e políticas de pós-graduação. Cadernos de Pesquisa, São Paulo, v. 34, n. 123, p. 583-611,set./dez. 2004.

\section{Notas}

1 Data not available for public access at the agency's website, we relied up on the help of technicians who, guided by the area coordination, identified, scanned and forwarded the following documents by e-mail: New Course Proposal Evaluation: (PUC- SP, 1971 [Master's degree] and 1980 [Doctoral degree], PUCRS, undated, UFRJ.Document (228), Nov. 1979, UFPE. Document (228), Nov. 1979, UFSC, 1996 and UFPB-JP, 1977); Opinion of the area to the New Course Proposal Evaluation of UFPB, Nov. 1979; New Course Proposal Evaluation: UERJ.Document (228), Nov. 1999; Accreditation Graduate program. Document (212), July 1978; Reports of visits to the programs (PPGSS-UFPE of the CAPES Committee, undated; PUC-RS of the CAPES Committee, 1991; PPGSS-UERJ of the CAPES Committee, 1998; PPGSS-PUC-SP of the CAPES Committee, 1982; PPGSS-PUC-SP of the CAPES Committee, 1984); Evaluation Form of the Graduate Program: 90/91. Evaluation of UFRJ, 1992; Evaluation Form of the Graduate Program: 92/93. Evaluation of UFRJ, 1994; Evaluation Form of the Graduate Program: 87/89. Evaluation of UFPE, 1990; Evaluation Form of the Graduate Program: 87/89. Evaluation of UFMA, 1993; Opinion of the CAPES Area Committee to the New Course Proposal Evaluation of UFSC, Oct. 1996; Resolution n. 10;1976, of the CAPES Technical-Administrative Council; CAPES's Opinion no. 1,538, of November 8, 1979; Proposal for the Renewal of the Accreditation of the Master's degree of UFRJ 1989 and the Evaluation Form of PUC-SP, 1990.

2 GeoCapes is a georeferential data tool. In a simplified way, it may be defined as a database that consists of referencing information according to its geographic location. It is a way of providing information about the most diverse scenarios in which CAPES participates or is related to. Available on: <http://geocapes.capes. gov.br/geocapes2/>. Accessed on: 05 Aug. 2016.

3 The Getúlio Vargas government promoted a new attitude towards schooling: it created the Ministry of Education and Public Health. This Ministry, "as early as April 1931, issued a set of six decrees organizing secondary education and the still non-existent Brazilian universities, known as the Francisco Campos reform " (SAVIANI, 2006, p.31). The creation of the University of São Paulo (the first to be created and organized according to the norms of the Statute of Brazilian Universities, of 1931) was registered in 1934. In 1935, the Secretary of Education of the Federal District, Anísio Teixeira, created the University of the Federal District, with a College of Education in which the Education Institute was located (JOSETTI; ARAÚJO, 2012).

4 In 1980, 86\% of university students were in private colleges (BELTRÃO; TEIXEIRA, 2004).

5 The datum on the accreditation process of the aforementioned Master's degree was extracted from the document New Course Proposal Evaluation of PUC-SP, 1971(Avaliação de Proposta de Curso Novo da PUC-SP, 1971).

6 In 1965, twenty-seven Master's and eleven Doctoral courses were operative, totaling thirty-eight courses in the country.

7 As we have seen, the recognition of Social Work as an area of knowledge in CAPES occurred in 1976 (according to area document 2017) and, in 1984, in CNPq (KOIKE et al., 1997).

8 The following data, on the current situation of the graduate programs of Area 32, were retrieved from the Sucupira Platform and comprise part of the Area Document - 2016.

9 Of these, two programs are in Home Economics.

10 The datum on the importance of qualification was extracted from the CAPES's Opinion No. 1,538, of November 8, 1979 (Parecer da CAPES n. 1.538 , de 8 de novembro de 1979).

11 Datum extracted from the document Proposal for Renewal of the Accreditation of UFRJ Master's Program 1989 (Proposta de Renovação do Credenciamento do Mestrado da UFRJ 1989).

12 The datum on the proposal for opening a Doctoral program in PUC-SP was extracted from the document New Course Proposal Evaluation of PUC-SP, 1980 (Avaliação de Proposta de Curso Novo da PUC-SP, 1980).

13 For example, in the United States the number of doctoral programs in Social Work spread between 1965 and 1975 (Crow; Kindelsperger, 1975).

14 This opinion portrays a situation that is currently being rectified, when one thinks of the internationalization of the programs. That is, there is no interest in the area, for the theoretical trajectory adopted in the Brazilian Social Work, to approach the North American programs by the distinction in terms of analytical perspective. Datum extracted from the document New Course Proposal Evaluation of PUC-SP, 1980 (Avaliação de Proposta de Curso Novo PUC-SP, 1980).

1516 17 Data extracted from the document New Course Proposal Evaluation of PUC-SP, 1980 (Avaliação de Proposta de Curso Novo PUC-SP, 1980).

18 Datum extracted from the document CAPES Commission Visit Report to the PPGSS-PUC-SP Program, 1982 (Relatório de Visita da Comissão da CAPES ao Programa de PPGSS-PUC-SP, 1982).

19 Datum extracted from the document CAPES Commission Visit Report to the PPGSS-PUC-SP Program, 1984 (Relatório de Visita da Comissão da CAPES ao Programa de PPGSS-PUC-SP, 1984).

20 Datum extracted from the document Evaluation Form of PUC-SP, 1990 (Ficha de Avaliação da PUC-SP, 1990).

21 Datum extracted from the document New Course Proposal Evaluation of UFPB-JP, 1977 (Avaliação de Proposta de Curso Novo da UFPBJP, 1977). 
22 Datum extracted from the document Opinion of the CAPES Area Committee to the New Course Proposal Evaluation of UFSC, Oct. 1996 (Parecer de Comissão de Área da CAPES a Avaliação de Proposta de Curso Novo da UFSC, out. 1996).

23 Name given at that moment by CAPES. Currently, the denomination is Technical-Scientific Council of Higher Education (CTC-ES).

24 Datum extracted from the document New Course Proposal Evaluation of UFMA, 1993 (Avaliação de Proposta de Curso Novo da UFMA, 1993).

\section{Maria Lúcia Teixeira Garcia}

lucia-garcia@uol.com.br

Professor of the Department of Social Work and of the Graduate Program in Social Policy of the Federal University of Espírito Santo (UFES)

\section{UFES}

514 Fernando Ferrari av. - Goiabeiras

Vitória - Espírito Santo - Brazil

Zip code: $29.075-910$

\section{Vera Maria Ribeiro Nogueira}

veramrn@gmail.com

Professor of the Graduate Program in Social Policy of the Catholic University of Pelotas (UCPel) and of the Graduate Program in Social Work of the Federal University of Santa Catarina (UFSC)

\section{UCPel}

373 Gonçalves Chaves st. - Centro

Pelotas - Rio Grande do Sul - Brazil

Zip code: $96.015-560$ 